\title{
Staphylococcal flora of the oral cavity and dental prostheses before and after kidney transplantation. Part 2
}

\author{
Flora gronkowcowa jamy ustnej i protez stomatologicznych przed i po \\ przeszczepie narządowym nerki. Część 2
}

\author{
Krzysztof Majchrzak', Ksenia Szymanek-Majchrzak ${ }^{2}$,Grażyna Młynarczyk ${ }^{2}$, \\ Elżbieta Mierzwińska-Nastalska ${ }^{1}$ \\ ${ }^{1}$ Katedra Protetyki Stomatologicznej, Warszawski Uniwersytet Medyczny \\ Department of Prosthodontics, Medical University of Warsaw \\ Head: prof. dr hab. n. med. Elżbieta Mierzwińska-Nastalska \\ ${ }^{2}$ Katedra Mikrobiologii Lekarskiej Warszawskiego Uniwersytetu Medycznego \\ Department of Medical Microbiology, Medical University of Warsaw \\ Head: prof. dr hab. n. med. Grażna Młynarczyk
}

KEY WORDS:

kidney transplantation, immunosuppression, Staphylococcal bacteria in the oral cavity

\section{Summary}

Introduction. Infections following a kidney transplantation can have exogenous and endogenous origin. The course of infection and prognosis are influenced by the type of microorganism and its drug-resistance profile. According to the current consensus, the dose and type of immunosuppressants modify the patient's immunological response, and increase the risk of opportunistic infections. At present, little is known about how a variety of immunosuppressive therapies may potentially affect the microbiological status of the oral cavity.

Aim of the study. To analyse drug resistance of isolated bacteria and to assess the impact of immunosuppression on the species composition in the examined locations of dentures and the pharynx.

Material and methods. The material consisted of 278 clinical samples collected from denture wearers ( both from the pharyngeal mucosa and the denture plate). Samples were collected from 57 kidney recipients (the study group) and
HASŁA INDEKSOWE:

przeszczep nerki, immunosupresja, bakterie Staphylococcus w jamie ustnej

\section{Streszczenie}

Wstep. Powikłania infekcyjne po przeszczepie narzadowym nerki moga mieć etiologię egzogenna $i$ endogenna. W przebiegu zakażenia $i$ dalszego rokowania przetrwania narzadu znaczenie ma rodzaj drobnoustroju przyczynowego i jego profil lekowrażliwości. Wedlug dzisiejszego stanu wiedzy dawki i rodzaj leków immunosupresyjnych modyfikuja odpowiedź immunologiczna pacjenta, powodując wzrost ryzyka występowania zakażeń oportunistycznych. Obecnie mało wiadomo na temat potencjalnych zależności różnych terapii immunosupresyjnych ze stanem mikrobiologicznym jamy ustnej.

Cel pracy. Analiza profili lekowrażliwości wyizolowanych bakterii oraz ocena wptywu leczenia immunosupresyjnego na sktad gatunkowy badanych mikronisz gardta i protez stomatologicznych.

Material i metody. Material stanowiło 278 próbek materiatu klinicznego od pacjentów użytkujacych protezy, który w postaci wymazów bezpośrednich pobrano z powierzchni błony śluzowej gardla i dośluzowej strony plyty protezy 
27 generally healthy individuals (the control group). Within the study group, 28 patients were identified, in whom swabs were taken three times in the period of 0-12 months postoperatively. The isolated strains were identified and their drug resistance determined. The results were subjected to statistical analysis.

Results. In the study group, bacteria isolated in the pharyngeal samples had multi-drug resistance (MDR) of 45.4\%; among the controls, the corresponding percentage was only $16.16 \%$. The number of MDR strains of S. epidermidis rose significantly at one year after transplantation. The summary increase in dosage of mycophenolate mofetil and azathioptine was associated with the growth in bacterial isolation.

Conclusions. In the period of one year after the kidney transplantation procedure, Staphylococcal population structure underwent variations in the oral cavity and on the denture plates, which may be due to the type and dosage regimen of immunosuppressive drugs. Increased bacterial drug resistance, especially concerning S. epidermidis, may adversely affect therapeutic options of potential infections in this group of patients.

\section{Introduction}

Kidney transplantation is now regarded as the most justified type of treatment of end-stage renal insufficiency. Infections are complications, which in the majority of cases occur in the first year postoperatively. They pose a therapeutic challenge, which may worsen the prognosis of organ's survival. ${ }^{1}$ In the etiology of bacterial infections, the identification of the causative microorganism is of utmost importance, followed by the determination of its drugresistance profile, so that targeted antibiotic therapy can be implemented. Patients with endstage renal insufficiency, who are scheduled for regular haemodialysis and are frequent attenders of health-care facilities, are at very high risk of colonization with infection-inducing multidrug od 57 chorych leczonych przeszczepem narzadowym nerki (grupa badana) i 27 osób ogólnie zdrowych (grupa kontrolna). W grupie badanej wyodrębniono 28 osób, u których wymazy byty wykonywane trzykrotnie $w$ okresie 0-12 miesięcy od operacji. Dla wyizolowanych szczepów przeprowadzono identyfikacje oraz oznaczenie lekooporności. Wyniki poddano analizie statystycznej.

Wyniki. Bakterie z błony śluzowej gardta grupy badanej byty w 45,4\% wielolekooporne (MDR), w kontrolnej jedynie w 16,16\% przypadków. Liczba szczepów MDR S. epidermidis istotnie wzrastała w pierwszym roku po przeszczepie. Wzrost sumarycznych dawek mykofenolanu mofetylu oraz azatiopryny byt powiazany ze wzrostem izolacji bakterii.

Wnioski. Struktura populacji bakterii Staphylococcus zmienia się $w$ jamie ustnej $i$ na protezach na przestrzeni roku od przeszczepu nerki, do czego moga się przyczyniać rodzaje i dawki leków immunosupresyjnych. Wrrastajaca lekooporność bakterii, szczególnie dotyczaca gatunku S. epidermidis może negatywnie wptynać na możliwości terapeutyczne ewentualnych zakażeń $w$ tej grupie pacjentów.

\section{Wstęp}

Przeszczep narządowy nerki jest wg. obecnych standardów najbardziej uzasadnioną formą leczenia schyłkowej niewydolności tego narządu. Powikłania infekcyjne, które w dużej mierze mają miejsce $\mathrm{w}$ pierwszym roku po operacji stanowią duży problem leczniczy mogący spowodować pogorszenie rokowania utrzymania przeszczepu. ${ }^{1} \mathrm{~W}$ etiologii zakażeń bakteryjnych niezmiernie istotne jest zidentyfikowanie drobnoustroju przyczynowego oraz określenie jego profilu lekowrażliwości i na tej podstawie opracowanie celowanej terapii antybiotykowej. W przypadku pacjentów ze schyłkową niewydolnością nerek, którzy regularnie odbywają hemodializy i wizytują placówki służby zdrowia, występuje szczególnie duże narażenie 
resistant (MDR) microorganisms. ${ }^{2}$ Infections with MDR bacteria have a much more problematic course than infections of identical aetiology but induced by drug-susceptible bacteria. $^{3-5}$ According to many studies, such events promote the loss of the transplanted organ ${ }^{6}$. Opportunistic infections in patients on immunosuppressants may be induced by both exogenous and endogenous flora. ${ }^{7}$ The mouth, and the dentures in it, constitute a specific reservoir of Staphylococci, ever-present on the epidermis and periodically on the mucosa of the alimentary tract and the airways. Little is known about the influence of immunosuppressants on the species composition and variability of oral bacterial flora. The first part of this research project outlined assessment results of microbiology on the pharyngeal mucosa and dentures of patients before and after kidney transplantation. Other objectives of this project included the drug-susceptibility analysis of isolated bacteria as well as evaluation of the impact of immunosuppressive therapy on species composition of the examined pharyngeal and denture microniches. This part of the project is entirely devoted to these issues.

\section{Material and methods}

The study material included 278 clinical samples obtained from patients utilizing removable dentures between 2012-2017. The material in the form of direct swabs was collected from both the pharyngeal mucosa and the denture plate contacting the prosthetic base. The patients comprised:

- 57 kidney recipients following the transplantation procedure in the General and Transplantation Surgery Clinic,

- 27 generally healthy individuals with no medication history, who underwent prosthetic treatment in the Department of Prosthodontics.

Inclusion and exclusion criteria have been na kolonizację wielolekoopornymi bakteriami oportunistycznymi (MDR - multidrug resistance),które mogą stanowić źródło infekcji. $^{2}$ Zakażenia bakteriami wielolekoopornymi są znacznie cięższe w przebiegu niż zakażenie o identycznej etiologii, lecz z udziałem bakterii wrażliwych. ${ }^{3-5}$ Jak wynika z opisanych w literaturze badań, częściej też w tych przypadkach dochodzi do utraty przeszczepu. ${ }^{6}$ Zakażenia oportunistyczne u osób przyjmujących leki immunosupresyjne mogą być wywołane zarówno florą egzogenną, jak i endogenną. ${ }^{7}$ Jama ustna i znajdujące się w niej protezy stomatologiczne stanowią swoisty rezerwuar bakterii Staphylococcus, stale obecnych na powierzchni skóry człowieka i okresowo na błonach śluzowych układu oddechowego i pokarmowego. O tym czy leki immunosupresyjne wpływają na skład gatunkowy lub zmienność flory bakteryjnej jamy ustnej niewiele jest wiadomo. W części pierwszej niniejszego opracowania przedstawiono wyniki oceny mikrobiologicznej powierzchni błony śluzowej gardła i protez stomatologicznych pacjentów przed i po przeszczepie narządowym nerki. Kolejnymi celami projektu badawczego była analiza profili lekowrażliwości wyizolowanych bakterii oraz ocena wpływu leczenia immunosupresyjnego na skład gatunkowy badanych mikronisz gardła i protez stomatologicznych. Część druga opracowania została w całości poświęcona powyższym zagadnieniom.

\section{Material i metody}

Badaniem objęto 278 próbek materiału klinicznego pobieranego w latach 2012-2017 od pacjentów użytkujących ruchome uzupełnienia protetyczne. Materiał w formie wymazów bezpośrednich $\mathrm{z}$ powierzchni błony śluzowej gardła i dośluzowej strony płyty protezy pobrano od:

- 57 chorych leczonych przeszczepem narządowym nerki w Klinice Chirurgii Ogólnej i Transplantacyjnej, 
described in detail in Part 1 of this research project. Direct smears were taken with sterile swab sets with transporting media. In the case of kidney recipients, 28 patients had their swabs taken three times: on the day of the transplantation procedure (collection " 0 "), after 6-9 weeks (collection "1") and after 6-12 months (collection “2").

The remaining 29 kidney recipients and the controls (27 individuals) had a single swab taken (collection "0"). Labeled and secured clinical samples were transported to the microbiological laboratory, and cultures were started within 48 hours of collection. Identification and drug susceptibility tests were performed by means of VITEK 2 device (Biomerieux). Results were interpreted in accordance with the current EUCAST guidelines.

Analysis of results was conducted in the following two areas:

- comparison of drug-susceptibility profiles of bacteria obtained from the study and the control groups following a single collection of the clinical material,

- variability of drug-susceptibility of bacteria in the observation period, which included three subsequent collections of the samples, in 28 kidney recipients, as well as the effect of immunosuppression on the composition of bacterial species in pharyngeal and denture microniches (further referred to as a "one-year period of observation").

Statistical analysis was carried out. The significance level was set at $p=0.05$. Statistical tests have been described in detail in the first part of the study.

\section{Results}

\section{Microbial drug resistance}

A total of 360 Staphylococcal strains were isolated on the pharyngeal mucosa and denture plates, of which only $20(5.5 \%)$ were
- 27 osób ogólnie zdrowych i nieprzyjmujących żadnych leków, które odbywały leczenie protetycznie w Zakładzie Protetyki Stomatologicznej.

Kryteria kwalifikacji i wykluczenia udziału w badaniu szczegółowo opisano w części pierwszej opracowania. Wymazy bezpośrednie wykonano przy pomocy jałowych zestawów pobraniowych $\mathrm{z}$ podłożem transportowym. W przypadku pacjentów leczonych przeszczepem narządowym nerki, u 28 osób wymazy były pobierane trzykrotnie: $w$ dniu transplantacji (pobranie "0"), po 6-9 tygodniach (pobranie „1") i po 6-12 miesiącach (pobranie "2").

U pozostałych 29 osób leczonych przeszczepem narządowym oraz pacjentów grupy kontrolnej (27 osób) wymazy były wykonywane jednokrotnie (pobranie ,0"). Oznaczone i zabezpieczone próbki materiału klinicznego przetransportowano do laboratorium mikrobiologicznego i w ciągu 48 godzin od pobrania wykonano posiewy. Przeprowadzono identyfikację oraz oznaczenie lekowrażliwości, wykorzystując urządzenia VITEK 2 firmy Biomerieux. Interpretację wyników wykonano zgodnie $\mathrm{z}$ aktualnymi wytycznymi EUCAST.

Wyniki analizowano w zakresie dwóch następujących obszarów: porównania profili lekowrażliwości bakterii między grupami: badaną i kontrolną po jednokrotnym pobraniu materiału klinicznego, a także u 28 osób po przeszczepie nerki, u których oceniano zmienności w lekowrażliwości bakterii na przestrzeni okresu obserwacji obejmującego trzy kolejne pobrania materiału oraz wpływ immunosupresji na skład gatunkowy mikroniszy gardła i protezy (celem uproszczenia w dalszej części publikacji zastosowano określenie: ,roczny okres obserwacji”).

W przeprowadzonym badaniu wykonano analizę statystyczną uzyskanych wyników. W pracy przyjęto graniczny poziom istotności $\mathrm{p}=0,05$. Zastosowano testy statystyczne, które szczegółowo opisano w części pierwszej opracowania. 
susceptible to all antibiotics, as tested with Vitek 2 (Biomerieux, France). In the study group, the incidence of these strains was recorded more frequently in pharyngeal swabs than those collected from denture plates. In the control group, the dependencies were reversed. However, the insufficient count of isolated microorganisms prevented statistical analysis, which would determine potential differences between the examined microniches.

The remaining 340 isolates to a lesser or greater extent comprised drug-resistant bacteria. The degree of resistance of pharyngeal and denture bacteria was studied indirectly by the evaluation of the number of antibiotics to which the examined strains were not susceptible. Comparison of pharyngeal and denture microniches in collection " 0 " revealed significant differences within the control group. Strains isolated on the denture plates manifested higher drug resistance than the pharyngeal ones $(p=0.027)$. In the study group, similar differences between the microniches were not reported. When strain resistance between individual groups is compared, significant differences were observed with regard to the area of pharyngeal mucosa, where isolated strains were more resistant than the bacteria present in the throats of healthy individuals $(\mathrm{p}=0.032)$.

Multi-drug resistant strains (MDR), comprising microorganisms not susceptible to at least one antibiotic out of three different groups, are of particular significance in medicine. In collection " 0 ", their percentage on denture plates in the study group was $40.7 \%$, and $37.8 \%$ among the controls. No significant differences between the examined groups $(p=0.76)$ were observed on visual evaluation of strains distribution and in statistical tests.

As for the analysis concerning the pharyngeal mucosa, unlike denture plates, the rate of MDR bacteria showed significant variations between the examined groups. MDR strains in solid organ

\section{Wyniki}

\section{Lekooporność drobnoustrojów}

W puli 360 wyizolowanych z powierzchni błony śluzowej gardła i protez szczepów Staphylococcus, jedynie 20 (5,5\%) stanowiło bakterie wrażliwe na wszystkie testowane urządzeniem Vitek 2 (Biomerieux, Francja) antybiotyki. W przypadku grupy badanej występowanie takich szczepów było obserwowane częściej w posiewach $\mathrm{z}$ powierzchni protez niż z gardła. Odwrotne zależności stwierdzono w grupie kontrolnej, jednak zbyt małe ilości izolowanych drobnoustrojów nie pozwoliły na przeprowadzenie testów statystycznych, określających potencjalne różnice między mikroniszami w badanych grupach osób.

Pozostałe 340 izolatów to w mniejszym lub większym stopniu bakterie oporne. Nasilenie oporności bakterii z powierzchni gardła i protezy analizowano pośrednio poprzez pomiar liczby antybiotyków, na które badane szczepy były niewrażliwe. Porównując mikroniszę gardła i protezy w pobraniu „0”, stwierdzono istotne różnice występujące $\mathrm{w}$ grupie kontrolnej. Szczepy izolowane z powierzchni protez były bardziej antybiotykooporne niż szczepy z powierzchni błony śluzowej gardła $(\mathrm{p}=0,027)$. $\mathrm{W}$ grupie badanej, podobnych różnic między mikroniszami nie zaobserwowano. W zestawieniu oporności szczepów pomiędzy grupami stwierdzono istotne różnice $\mathrm{w}$ zakresie powierzchni błony śluzowej gardła, gdzie izolowane bakterie były bardziej oporne niż bakterie $\mathrm{z}$ gardła osób ogólnie zdrowych $(\mathrm{p}=0,032)$.

W puli drobnoustrojów wykazujących oporność na antybiotyki, szczególne znaczenie w medycynie mają szczepy określane jako wielolekooporne (MDR - multidrug resistant), czyli niewrażliwe na działanie przynajmniej jednego antybiotyku $\mathrm{z}$ trzech różnych grup. W pobraniu „0", ich odsetek na powierzchni protez wynosił $40,7 \% \mathrm{w}$ grupie badanej, a w grupie kontrolnej $37,8 \%$. W ocenie 
transplants accounted for as many as $45.4 \%$ of all isolates; in generally healthy subjects their number was only $16.16 \%$. This difference was confirmed statistically $(p=0.017)$. In collection "0", the occurrence of MDR bacteria was much more frequent in the study group than in the controls. The overall drug resistance of bacteria isolated from both microniches was the highest in the $6-9$ week period from the transplant, which is illustrated by the graphical interpretation of the statistical test in Figure 1. Resistance to individual drugs in subsequent collections is presented in Table 1 .

In one-year period of observation of kidney recipients, the percentage of MDR strains isolated on denture plates rose significantly between collection " 0 " and " 1 ", from $46.67 \%$ to $70.37 \%(p=0.031)$. In the next recording at 6-12 months postoperatively, a drop in the incidence was observed (from $70.37 \%$ to $57.14 \%$ ), however, in this case the difference in the number of MDR strains between collections "1" and " 2 " was not significant statistically ( $>>0.05)$.

The percentage of MDR bacteria on the pharyngeal mucosa underwent comparable change as the one for dentures. Following an initial increase from $53.33 \%$ to $72 \%$, a drop to $56.25 \%$ was observed. In statistical analysis, no significant difference was observed in the examined periods $(\mathrm{p}>0.05)$.

In the group of kidney recipients, the study focused on the varied incidence of strains of $S$. epidermidis, the most common MDR species in three subsequent collections of the clinical samples. Both microniches were examined for differences in MDR bacteria isolates, however, statistical significance concerned only microorganisms identified on denture plates $(p=0.032)$. Their multi-drug resistance varied in time, which is shown in Fig. 1. In the period of three collections of the clinical material, the incidence of $S$. epidermidis MDR strains was relatively constant, and fluctuated between wizualnej rozkładu szczepów oraz w testach statystycznych nie stwierdzono istotnych różnic pomiędzy badanymi grupami $(p=0,76)$.

$\mathrm{W}$ analizie przeprowadzonej dla powierzchni błony śluzowej gardła, w odróżnieniu od powierzchni protez, odsetek bakterii MDR wykazywał znaczne różnice między grupami. Szczepy wielolekooporne u pacjentów leczonych przeszczepem narządowym stanowiły aż $45,4 \%$ wszystkich wykrywanych, natomiast u osób ogólnie zdrowych takich szczepów było jedynie $16,16 \%$. Różnica między grupami została potwierdzona statystycznie $(\mathrm{p}=0,017)$. W pobraniu „0" bakterie wielolekooporne pojawiały się znacznie częściej w grupie badanej niż w grupie kontrolnej.

W rocznej obserwacji chorych po przeszczepie nerki, odsetek szczepów MDR wykrywanych na powierzchni protez istotnie wzrósł pomiędzy pobraniem ,0" a ,1" z 46,67\% do $70,37 \%(p=0,031)$. W kolejnym oznaczeniu w okresie 6 -12 miesięcy od operacji odnotowano spadek częstotliwości (z 70,37\% do 57,14\%), jednak w tym przypadku między pobraniami „1" a „2" różnica w liczbie szczepów MDR nie była statystycznie istotna $(\mathrm{p}>0,05)$.

Odsetek bakterii wielolekoopornych na powierzchni błony śluzowej gardła zmieniał się analogicznie jak w przypadku protez. Po początkowym wzroście z 53,33\% do $72 \%$, następował spadek do $56,25 \%$. W analizie statystycznej nie stwierdzono istotnych różnic między badanymi okresami ( $p>0,05)$. Ogólna lekooporność bakterii izolowanych z obu mikronisz była najwyższa w okresie 6-9 tygodnia od przeszczepu, co ilustruje graficzna interpretacja testu statystycznego na rycinie 1 . Oporność na poszczególne leki w kolejnych pobraniach przedstawiono w tabeli 1 .

$\mathrm{W}$ grupie chorych po przeszczepie nerki przebadano także zmiany w częstości występowania szczepów MDR najliczniejszego gatunku, jakim był $S$. epidermidis, w czasie trzech kolejnych pobrań materiału klinicznego. 
Ta b le 1. Number of occurrences and percentage of resistance to individual antibiotics among isolated Staphylococcus strains in three consecutive samples

\begin{tabular}{|l|c|c|c|c|c|c|}
\hline \multicolumn{1}{|c|}{ Antibiotic } & \multicolumn{2}{c|}{$\begin{array}{c}\text { Collection ,0” } \\
\text { number/percentage }\end{array}$} & \multicolumn{2}{c|}{$\begin{array}{c}\text { Collection ,1” } \\
\text { number/percentage }\end{array}$} & \multicolumn{2}{c|}{$\begin{array}{c}\text { Collection „2” } \\
\text { number/percentage }\end{array}$} \\
\hline Cefoxitin & 44 & $27.67 \%$ & 35 & $66.04 \%$ & 28 & $43.08 \%$ \\
\hline Oxacillin & 46 & $28.93 \%$ & 33 & $62.26 \%$ & 25 & $38.46 \%$ \\
\hline Lvofloxacin & 26 & $16.35 \%$ & 24 & $45.28 \%$ & 24 & $36.92 \%$ \\
\hline Gentamicin & 20 & $12.58 \%$ & 19 & $35.85 \%$ & 15 & $23.08 \%$ \\
\hline $\begin{array}{l}\text { Induced clindamycin } \\
\text { resistance (ICR) }\end{array}$ & 25 & $15.72 \%$ & 10 & $18.87 \%$ & 5 & $7.69 \%$ \\
\hline Clindamycin & 50 & $31.45 \%$ & 18 & $33.96 \%$ & 12 & $18.46 \%$ \\
\hline Teicoplanin & 18 & $11.32 \%$ & 2 & $3.77 \%$ & 4 & $6.15 \%$ \\
\hline Tetramycin & 39 & $24.53 \%$ & 14 & $26.42 \%$ & 11 & $16.92 \%$ \\
\hline Rifampicin & 4 & $2.52 \%$ & - & & 1 & $1.54 \%$ \\
\hline Erythromycin & 73 & $45.91 \%$ & 26 & $49.06 \%$ & 22 & $33.85 \%$ \\
\hline $\begin{array}{l}\text { Trimethoprim / } \\
\text { Sulfmetoksazol }\end{array}$ & 12 & $7.55 \%$ & 10 & $18.87 \%$ & 10 & $15.38 \%$ \\
\hline Vancomycin & 1 & $0.63 \%$ & - & - & - & - \\
\hline
\end{tabular}

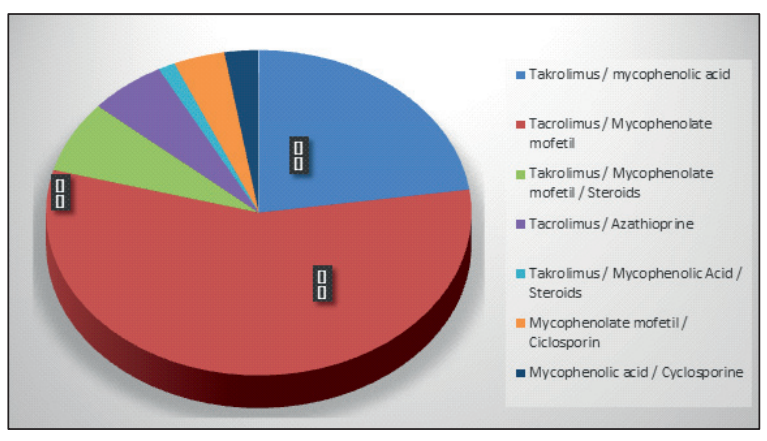

Fig. 3. Schemes of immunosuppressive treatment in patients after organ transplantation of the kidney.

Ryc. 3. Schematy leczenia immunosupresyjnego u pacjentów po przeszczepie narząowym nerki.

$30.8 \%$ and $35.9 \%$. There was a significant drop in the incidence of non-MDR strains, from the initial $66.7 \%$, through $6.7 \%$ in the second collection, to $26.7 \%$ in the third one. Major changes in the non-MDR group, which occur along minor changes within MDR strains, resulted from significant differences in the sizes of both groups. In conclusion, the number of
Różnice między okresami w zakresie izolowanych bakterii MDR były obserwowane dla obu mikronisz, jednak istotność statystyczna dotyczyła wyłącznie drobnoustrojów z powierzchni protez ( $\mathrm{p}=0,032)$. Ich wielolekooporność zmieniała się w czasie, co ilustruje rycina $2 . \mathrm{Na}$ przestrzeni trzech pobrań materiału klinicznego, częstość szczepów S. epidermidis MDR w kolejnych próbach była względnie stała i wahała się między $30,8 \%$ a 35,9\%. Znacząco zmniejszyła się częstość szczepów nie-MDR z początkowych $66,7 \%$ przez $6,7 \% \mathrm{w}$ drugim pobraniu do $26,7 \% \mathrm{w}$ trzecim pobraniu. Duże zmiany $\mathrm{w}$ grupie drobnoustrojów nie-MDR, które towarzyszą małym zmianom szczepów MDR były podyktowane znaczną różnicą $\mathrm{w}$ liczności obu grup. Podsumowując powyższy wynik, liczba szczepów wielolekoopornych S. epidermidis na protezie wzrastała w czasie przy jednoczesnym progresywnym zmniejszeniu liczby drobnoustrojów nie wykazujących 


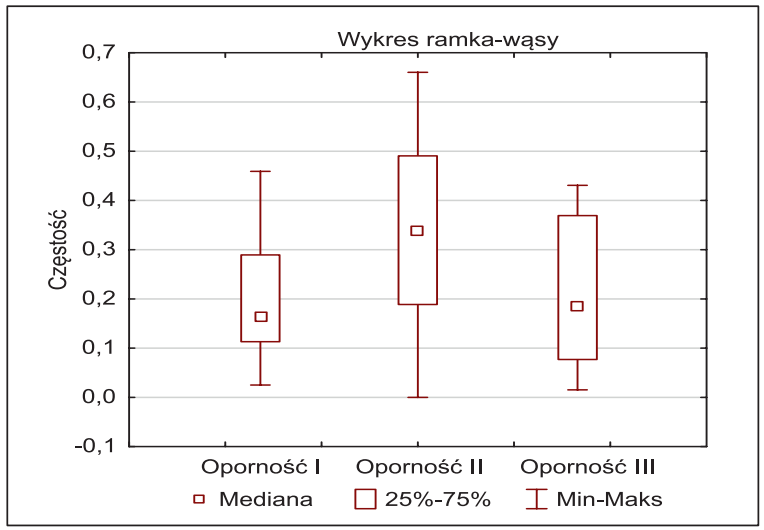

Fig. 1. Graphical interpretation of the statistical test of general bacterial resistance in three consecutive intakes (resistance I, resistance II, resistance III).

Ryc. 1. Interpretacja graficzna testu statystycznego ogólnej oporności bakterii w trzech kolejnych pobraniach (oporność I, oporność II, oporność III).

MDR strains of $S$. epidermidis on dentures rose in time with concomitant progressive fall in the number of microorganisms not manifesting multi-drug resistance. Similar analyses for the remaining thirteen species were not conducted due to small count within individual MDR strains.

Impactofimmunosuppressionon Staphylococcal flora present in the throat and on denture plates

Patients treated with a kidney transplantation procedure, who were monitored for the period covering three subsequent collections of the clinical material, were at the same time undergoing seven different protocols of immunosuppressive therapy. The one that was employedmost frequently involved the following drug combination: calcineurin inhibitors (Tac - tacrolimus), drugs impeding cell proliferation (MMF - mycophenolate mofetil, MPA - mycophenolic acid) and glucocorticosteroids (GS). These drugs, administered in predetermined combinations (Tac/MPA, TacMMF, Tac/MMF/Gs), comprised the three most common treatment protocols, which covered $86 \%$ of all cases. The present

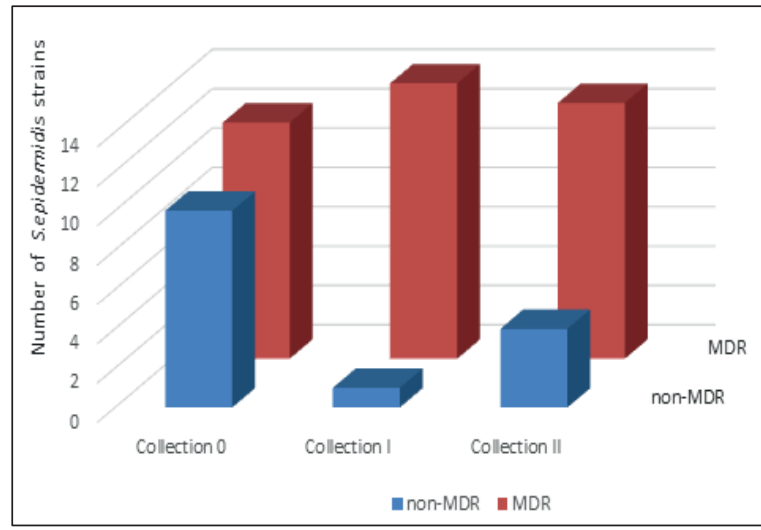

Fig. 2. The number of MDR and non-MDR S. epidermidis strains in the period of three subsequent collections of the clinical material.

Ryc. 2. Liczba szczepów S. epidermidis MDR i nie-MDR w okresie trzech kolejnych pobran materiatu klinicznego.

wielolekooporności. Podobnych analiz dla pozostałych 13 gatunków z uwagi na niewielkie liczności poszczególnych szczepów MDR nie przeprowadzono.

Wpływ leczenia immunosupresyjnego na flore gronkowcowa powierzchni gardła i protez

Pacjenci leczeni przeszczepem narządowym nerki, których objęto obserwacją obejmującą okres trzech pobrań materiału klinicznego, otrzymywali w tym czasie leczenie immunosupresyjne wg 7 różnych schematów (ryc. 3). Najczęstsza forma terapii osób uczestniczących w badaniu była oparta na kombinacji leków należących do grupy inhibitorów kalcyneuryny (Tac - takrolimus), leków hamujących podziały komórkowe (MMF - mykofenolan mofetylu, MPA - kwas mykofenolowy) oraz glikokortykosteroidów (GS). Powyższe leki w odpowiednim zestawieniu stanowiły trzy najczęściej stosowane schematy leczenia obejmujące $86 \%$ wszystkich przypadków (Tac/MPA, TacMMF, Tac/MMF/Gs). W niniejszym opracowaniu oceniono czy istnieje związek rodzaju zastosowanej terapii z częstością występowania szczepów Staphylococcus. Z uwagi na 
study assessed whether there was a correlation between the type of therapy and the incidence of Staphylococcal strains. Due to the limited count of some isolated species, analyses were performed for the two most commonly detected ones (S. epidermidis, S. haemolyticus). A significant relationship was confirmed between the three above-mentioned immunosuppression therapeutic protocols and the presence of $S$. epidermidis and $S$. haemolyticus species (Fisher's exact test $\mathrm{p}=0.049$ ). In further analyses, during which treatment protocols were limited to the two most common ones (Tac/MPA, Tac/ MMF), a much higher statistical significance was obtained $(p=0.016)$, which confirms the existence of the examined correlations. As for numeral analysis, "Tac/MPA" protocol resulted in a higher incidence of $S$. haemolyticus strains $(64 \%)$ in comparison with the "Tac/MMF" protocol (36\%). A reverse trend was recorded for the $S$. epidermidis strains, where the "Tac/ MPA" protocol was responsible for their lower incidence in comparison with "Tac/MMF".

The present research project provided for evaluating the impact of doses of specific immunosuppressive drugs on the number of Staphylococcal strains isolated in a given period of observation. The conducted analysis (multiple regression model) revealed that combined doses of mycophenolate mofetil $(p=0.005)$, mycophenolic acid $(p=0.01)$ and azathioprine $(p=0.003)$ significantly affected the number of detected bacterial strains. The magnitude of effect of individual drugs varied, but was the highest for mycophenolate mofetil. In the employed statistical test the value of coefficient of determination $\mathrm{R}^{\wedge} 2$ was 0.38 , then only $38 \%$ variability of the number of strains could be accounted for by the proposed model. In numerical interpretation, it means that the summary increase of the dose of, for instance, mycophenolate mofetil (between collections) by $1 \mathrm{~g}$ would result in the increase in the number of strains by 0.38 . ograniczoną liczebność części wyizolowanych gatunków, przeprowadzono analizy dla dwóch najczęściej wykrywanych (S. epidermidis, $S$. haemolyticus). Stwierdzono istotny związek pomiędzy trzema wymienionymi schematami leczenia immunosupresyjnego $\mathrm{z}$ występowaniem drobnoustrojów należących do gatunków S. epidermidis, S. haemolyticus (test dokładny Fishera $\mathrm{p}=0,049$ ). $\mathrm{W}$ dalszych analizach, przy ograniczeniu schematów leczenia do dwóch najczęstszych (Tac/MPA, Tac/MMF), osiągano znacznie wyższą istotność statystyczną $(\mathrm{p}=0,016)$, co potwierdza występowanie badanych zależności. W interpretacji liczbowej przy schemacie leczenia „Tac/MPA” częstość występowania szczepów $S$. haemolyticus była większa $(64 \%)$ w porównaniu ze schematem „Tac/MMF” (36\%). Odwrotna tendencja występowała w przypadku szczepów S. epidermidis, gdzie przy schemacie „Tac/MPA” te drobnoustroje pojawiały się rzadziej w porównaniu ze schematem „Tac/MMF”.

W projekcie badawczym przebadano także wpływ dawek poszczególnych leków immunosupresyjnych na liczby szczepów Staphylococcus izolowanych w branym pod uwagę okresie obserwacji. W wyniku przeprowadzonej analizy (model regresji wielorakiej) stwierdzono, iż sumaryczne dawki leków: mykofenolanu mofetylu ( $\mathrm{p}=0,005)$, kwasu mykofenolowego $(p=0,01)$ i azatiopryny $(p=0,003)$ istotnie wpływały na liczby wykrywanych szczepów bakteryjnych. Siła wpływu poszczególnych leków była zróżnicowana, największa w przypadku mykofenolanu mofetylu. W zastosowanym teście statystycznym wartość współczynnika determinancji $\mathrm{R}^{\wedge} 2$ wynosiła 0,38 , zatem tylko 38\% zmienności liczby szczepów było wyjaśnione przez opracowany model. W interpretacji liczbowej oznacza to, że zwiększenie sumarycznej dawki np. mykofenolanu mofetylu (w okresie między pobraniami) o $1 \mathrm{~g}$ powodowałby wzrost liczby szczepów o 0,38. 


\section{Discussion}

More than $90 \%$ of all isolated and identified strains collected from both groups of patients manifested resistance to antibiotics which the VITEK 2 system (Biomerieux) is capable of diagnosing. For the past several years, a constant rise in antibiotic therapy has been observed, resulting in the increase of drug resistance among many species of bacteria and fungi. ${ }^{8-10}$ The medical condition of chronically ill patients requires regular administration of antibiotics more frequently than in healthy individuals. Patients with renal insufficiency subjected to dialysis are at high risk of urinary infections, necessitating the administration of broadspectrum antibiotics such as vancomycin. ${ }^{11}$ The downside of such therapies is the emergence of bacterial strains, the best examples of which are Methicillin-Resistant $S$. aureus (MRSA), Methicillin-Resistant Coagulase-Negative Staphylococci (MRCNS) or VancomycinResistant Coagulase-Negative Staphylococci (VRCNS), which in the case of symptomatic infection may dramatically complicate treatment, posing a threat to patient's health or life. ${ }^{2}$ In the present study, the following strains were isolated: 98 MRCNS (54 and 44 from denture and pharyngeal microniches, respectively), 3 MRSA and one VRCNS strain in kidney recipients. These bacteria colonized the investigated microniches without producing symptoms of infection. It is a characteristic feature of opportunistic microorganisms whose balance is maintained in a healthy body. Such strains, however, possess encoded information in their genes concerning mechanisms of resistance to a multitude of antibiotics, which can be passed on to more hostile pathogens. ${ }^{13}$ The same mechanism enables Staphylococci to acquire drug resistance; then exposure to a given antibiotic is not necessary, only contact with other species which have the appropriate genes is needed. ${ }^{14}$

\section{Dyskusja}

Ponad 90\% wszystkich wyizolowanych i oznaczonych szczepów, pochodzących od obu grup pacjentów, wykazywało oporność na antybiotyki, znajdujące się na kasetach diagnostycznych systemu VITEK 2 firmy Biomerieux. Przez ostatnie kilkanaście lat obserwowany jest stały wzrost wykorzystania antybiotyków w medycynie, czego efektem jest nasilenie zjawiska lekooporności wśród drobnoustrojów licznych gatunków bakterii i grzybów. ${ }^{8-10}$ Osoby przewlekle chore z uwagi na ich stan ogólny, niejednokrotnie przyjmują antybiotyki z większą częstością niż osoby zdrowe. Pacjenci z niewydolnością nerek, odbywający dializy, są często narażeni na zapalenie dróg moczowych, które wiąże się z koniecznością przyjmowania antybiotyków o szerokim spektrum działania, jak np. wankomycyna. ${ }^{11}$ Negatywną konsekwencją takich terapii jest wyselekcjonowanie szczepów bakteryjnych jak MRSA (Methicillin - Resistant S. aureus), MRCNS (Methicillin - Resistant Coagulase - Negative Staphylococci) czy VRCNS (Vancomycin - Resistant Coagulase Negative Staphylococci), które w sytuacji wystąpienia objawowego zakażenia, mogą przysporzyć dużych trudności w leczeniu, stanowiąc poważne zagrożenie dla zdrowia i życia chorego. ${ }^{2} \mathrm{~W}$ niniejszym badaniu wyizolowano 98 szczepów MRCNS (54 z mikroniszy protez, 44 z gardła), 3 MRSA oraz jeden szczep VRCNS od osób po przeszczepie nerki. Bakterie te kolonizowały badane mikronisze, nie wywołując objawowego zakażenia. Jest to cecha charakterystyczna dla drobnoustrojów oportunistycznych, z którymi ludzki organizm w warunkach zdrowia utrzymuje równowagę. Takie szczepy posiadają jednak w swoich genach zakodowane informacje dotyczące mechanizmów oporności na liczne antybiotyki, które mogą przekazywać innym groźniejszym patogenom chorobotwórczym. ${ }^{13} \mathrm{~W}$ tym samym mechanizmie 
The present studies have analysed the intensification of drug resistance among bacteria isolated on the pharyngeal mucosa and denture plates in the examined groups with the conclusion that the most resistant strains were present in the denture microniche both in kidney recipients and the generally healthy individuals. When strains in both groups are compared, a marked tendency towards higher drug resistance was observed in pharyngeal samples in the study group. Similar observations concerned MDR bacteria. Increased drug resistance of microorganisms isolated in kidney recipients is an expected outcome and is reflected by the patients' general health. Risk factors of MDR strains acquisition include frequent contact with health care facilities or dialysis centers and repeated treatments with antibiotics. ${ }^{14}$ MDR bacteria infections produce much more serious sequelae than those caused by the same species not manifesting multi-drug resistance..$^{3,4}$ Unfortunately, as the present studies show, microbiological diagnosis of a patient can easily miss a number of drug-resistant strains that colonize denture plates since there are no procedures which would include denture swabs in preoperative screening examinations for every patient undergoing surgery. Nasal smears for MRSA carrier state may also result in omission of this "alarm bell" microorganism; according to research, absence of MRSA in the nose does not have to indicate its absence in the oral cavity, and vice versa. ${ }^{15}$

The incidence of MDR strains over a 6-12-month period, in the group of 28 patients undergoing observation was markedly elevated in the first months following the transplantation procedure for both pharyngeal and denture niches, only to fall to values similar to those obtained in the first collection. This variation, relative to time, may be due to a difference in the number of strains isolated in subsequent collections, and may not indicate the actual rise or fall of MDR intensification. A significant bakterie Staphylococcus mają także zdolność nabywania oporności na leki, wówczas nie jest konieczna ekspozycja na dany antybiotyk, a jedynie styczność z innymi gatunkami, posiadającymi odpowiednie geny. ${ }^{14}$

W niniejszych badaniach analizując nasilenie lekooporności izolowanych z powierzchni błony śluzowej gardła i protez bakterii w poszczególnych grupach, można wnioskować, iż najbardziej oporne szczepy występowały w mikroniszy protez zarówno wśród osób leczonych nerkozastępczo, jak i osób ogólnie zdrowych. Porównując szczepy między grupami, zaobserwowano wyraźną tendencję do wyższej oporności na leki bakterii z powierzchni gardła w grupie badanej. Podobne obserwacje dotyczyły bakterii wielolekoopornych (MDR). Większe nasilenie lekooporności wśród drobnoustrojów izolowanych od osób leczonych nerkozastępczo jest wynikiem uzasadnionym ogólnym stanem chorych. Wśród czynników ryzyka nabywania szczepów MDR wymieniane są częste kontakty z placówkami służby zdrowia, wizyty w ośrodkach dializ i powtarzające się terapie antybiotykami. ${ }^{14}$ Infekcje wywołane przez bakterie MDR sa znacznie gorsze w skutkach niż choćby te spowodowane tymi samymi gatunkami nie wykazującymi wielolekooporności. ${ }^{3,4}$ Niestety jak pokazują niniejsze badania, $\mathrm{w}$ diagnostyce mikrobiologicznej pacjenta przed zabiegiem bardzo łatwo jest pominąć szereg lekoopornych szczepów, które zasiedlają protezy stomatologiczne. Nie istnieją bowiem procedury, w których wymazy z protez byłyby częścią badań skryningowych, którymi jest objęty każdorazowo pacjent przed zabiegami chirurgicznymi. Wymazy z przedsionka nosa w kierunku wykrycia nosicielstwa MRSA bez wymazów z jamy ustnej mogą również spowodować pominięcie tego drobnoustroju alarmowego, gdyż jak dowodzą badania, brak nosicielstwa w jamie nosowej nie musi być jednoznaczny $\mathrm{z}$ brakiem wyżej wymienionego gatunku w jamie ustnej i odwrotnie. ${ }^{15}$ 
number of $S$. epidermidis strains, which were isolated during every examination period, made it possible to analyse the intensification of drug resistance of this particular species. Based on statistics, one can assume that indeed there are more MDR strains of $S$. epidermidis in the first year following the transplantation procedure. Reports in world literature also indicate that the percentage of MDR bacteria rises after the surgery, and this observation is not related to immunosuppression but to exposure of patients to microorganisms in health care facilities, prescribed antibiotics, and medical procedures which often involve transfer of microorganisms by medical personnel. ${ }^{16,17}$

Immunosuppressive therapy aims at preventing the rejection of the transplanted organ. To fulfil that goal, and at the same time minimize the risk of adverse side effects like infections and neoplastic transformations, it is necessary to customize the choice of medication taking into account a number of factors related to both the donor and the recipient of the organ. The general rule is to implement multi-drug protocols where individual drugs manifest a different immunosuppressive activity. It will maximize the prevention of transplant rejection, and at the same time minimize the dosage of immunosuppressive drugs. In the group of 28 patients in the one-year period of observation as many as seven treatment protocols were undertaken, most of which comprising the following combination of drugs: calcineurin inhibitors (Tacrolimus), drugs preventing cell proliferation, and glucocorticosteroids. A research question emerged of whether a given treatment modality is possibly related to the colonization of the mouth by specific Staphylococcal species. Due to the limited count within individual species, statistical analyses were limited to the two most frequently isolated species, namely $S$. epidermidis and $S$. haemolyticus. It was revealed that the two-drug combination of tacrolimus with mycophenolic
Częstość występowania szczepów MDR na przestrzeni 6-12 miesięcy, w grupie 28 osób objętych obserwacją wzrastała znacznie w pierwszych miesiącach po przeszczepie zarówno w przypadku bakterii z powierzchni gardła jak i protez, aby następnie spaść do wartości zbliżonych do tych z pierwszego pobrania. Powyższa zmienność w czasie może być podyktowana różnicą w liczbie szczepów izolowanych w kolejnych pobraniach i nie świadczyć o faktycznym wzroście lub spadku nasilenia wielolekooporności. Znaczna liczność szczepów S. epidermidis, która była izolowana w trakcie każdego okresu badania pozwoliła na analizę nasilenia wielolekooporności na przykładzie tego gatunku. Na podstawie testów statystycznych można przyjąć, iż istotnie przybywa szczepów wielolekoopornych $S$. epidermidis $\mathrm{w}$ okresie pierwszego roku od przeszczepu. W doniesieniach ze światowej literatury również pojawiają się przesłanki, iż odsetek bakterii MDR wzrasta po przeszczepie i nie jest to związane z przyjmowanymi lekami immunosupresyjnymi, lecz ekspozycją pacjenta na drobnoustroje w placówkach służby zdrowia, przyjmowaniem antybiotyków oraz zabiegami medycznymi, w trakcie których często dochodzi do przeniesienia drobnoustrojów przez personel medyczny. ${ }^{16,17}$

Leczenie immunosupresyjne ma na celu zapobieganie odrzucania przeszczepu. Aby spełnić to założenie i jednocześnie zminimalizować ryzyko skutków ubocznych w postaci zakażeń oraz nowotworzenia niezbędna jest indywidualizacja w doborze leków uwzględniając szereg czynników zależnych zarówno od dawcy, jak i od biorcy organu. Ogólnie przyjętą zasadą jest stosowanie schematów wielolekowych, gdzie poszczególne środki farmakologiczne celują w inny obszar działań immunosupresyjnych. Takie postępowanie ma na celu maksymalizację ochrony przeszczepu przed procesem odrzucania przy jednoczesnym zminimalizowaniu dawek leków immunosupresyjnych. W grupie 28 
acid was the most conducive to the colonization by $S$. heamolyticus strains in comparison with the tacrolimus-mycophenolate mofetil combination. In the case of $S$. epidermidis, the exactly reverse dependency was observed: patients on tacrolimus-mycophenolate mofetil combination had a higher frequency of strain isolations. The analysis also covered a potential influence of summary doses of individual immunosuppressive agents on the incidence of individual species. Results of similar studies were published in 2013 by Patricia I. Diaz et al, ${ }^{6}$ who used advanced methods of molecular biology to compare the oral microbiom of patients on or without immunosuppression. The researchers claimed that the frequency of Staphylococcal isolates increased as the doses of glucocorticosteroids and mycophenolate mofetil were higher. In the present study, mycophenolate mofetil, a chemotherapeutic agent which inhibits cell proliferation, as well as mycophenolic acid and azathioprine, significantly affected colonization by Staphylococci. The highest positive effect was observed for mycophenolate mofetil, but according to the statistical analysis its impact was fairly moderate, which is confirmed by the result of multiple regression test and coefficient of determination at $\mathrm{R}^{\wedge} 2=0.38$.

\section{Summary}

Microorganisms which are isolated on the pharyngeal mucosa and denture plates are in the majority of cases drug resistant strains. Most of them are MDR, and their pharyngeal incidence was higher in the study group than among the controls. In the case of dentures, the resistance of the dominant $S$. epidermidis strains relatively rose in time in the period of observation that covered three collections of the sample material.

It is also worth noting that the total number of Staphylococcal strains increased when pacjentów objętych roczną obserwacją, stosowanych było aż 7 schematów leczenia, z czego większość stanowiła kombinację leków z grupy inhibitorów kalcyneuryny (takrolimus), leków hamujących podziały komórkowe oraz glikokortykosteroidów. W badaniach postawiono pytanie, czy dany schemat leczenia może mieć związek z kolonizacją środowiska jamy ustnej przez konkretne gatunki należące do rodzaju Staphylococcus. Z uwagi na ograniczone liczności poszczególnych gatunków, analizy statystyczne przeprowadzono dla dwóch najczęściej izolowanych czyli $S$. epidermidis i $S$. haemolyticus. Stwierdzono, iż schemat leczenia dwulekowego takrolimusa z kwasem mykofenolowym bardziej sprzyjał kolonizacji szczepom S. heamolyticus w porównaniu ze schematem takrolimus - mykofenolan mofetylu. W przypadku gatunku S. epidermidis obserwowano dokładnie odwrotną zależność, gdzie większa częstość izolacji szczepów występowała u osób przyjmujących takrolimus z mykofenolanem mofetylu. W analizie wyników ocenie poddano także potencjalny wpływ sumarycznych dawek poszczególnych leków immunosupresyjnych na częstość występowania danych gatunków. Wyniki podobnych badań były opublikowane w 2013 roku przez Diaz i wsp., ${ }^{6}$ którzy wykorzystując zaawansowane metody biologii molekularnej porównywali mikrobiom jamy ustnej osób przyjmujących immunosupresję z osobami nieprzyjmującymi. Badacze stwierdzili, iż częstość izolacji bakterii należących $\mathrm{m}$. in. do rodzaju Staphylococcus zwiększała się przy zwiększających się dawkach glikokortykosteroidów i mykofenolanu mofetylu. W badaniach własnych mykofenolan mofetylu, lek należący do grupy chemioterapeutyków hamujących podziały komórkowe, kwas mykofenolowy oraz azatiopryna, także istotnie wpływały na kolonizację bakteriami Staphylococcus. Największy dodatni wpływ był obserwowany w przypadku mykofenolanu mofetylu, jednak na podstawie przeprowadzonych testów statystycznych 
immunosuppressive agents were administered, which in the present study was correlated with the increasing doses of mycophenolate mofetil, mycophenolic acid and azathioprine.

\section{Conclusions}

Based on the conducted studies, it can be concluded that the increase in the number of $S$. epidermidis multi-drug resistant strains isolated from the surface of prostheses may indicate a general tendency for the increase of resistance of bacteria of various species on prostheses in patients after kidney transplantation. MDR bacteria that cause symptomatic infections can lead to death in extreme situations, as antibiotics do not show efficacy against these microorganisms. It would therefore be advisable to confirm or deny the above conclusion if further studies were carried out on a range of other types of microorganisms. In the light of knowledge concerning microbiological causes of postoperative complications, this would provide extremely valuable information that would allow the modification or development of new anti-infective prophylaxis methods, which would include, for example, periodic disinfection or sterilization of dental prostheses.

Connections between doses of immunosuppressive drugs, treatment regimens and the presence of specific bacteria in the oral cavity are still not well-understood knowledge. The present study indicates a further need to explore the subject and implementation of safe immunosuppressive therapies for people treated with renal replacement organ transplantation, which take into account the microbiological status of one of the most important microbial reservoirs, which is the oral cavity. można stwierdzić, iż siła tego oddziaływania była dość umiarkowana, o czym świadczy wynik testu regresji wielorakiej i wskaźnik determinancji na poziomie $\mathrm{R}^{\wedge} 2=0,38$.

\section{Podsumowanie}

Drobnoustroje izolowane z powierzchni gardła i protez to szczepy w większości przypadków oporne na antybiotyki. Duży ich odsetek stanowią bakterie wielolekooporne, których częstość występowania na powierzchni gardła grupy badanej była wyższa niż u osób grupy kontrolnej. W przypadku protez, oporność szczepów gatunku dominującego $S$. epidermidis, na przestrzeni okresu obserwacji obejmującego trzy pobrania materiału wykazywała relatywny wzrost w czasie. Na uwagę zasługuje fakt, iż ogólna liczba szczepów Staphylococcus wykazywała wzrost w okresie przyjmowania leków immunosupresyjnych, co w niniejszych badaniach było skorelowane ze wzrastającymi dawkami leków mykofenolanu mofetylu, kwasu mykofenolowego oraz azatiopryny.

\section{Wnioski}

$\mathrm{Na}$ podstawie przeprowadzonych badań można wnioskować, iż wzrost liczby szczepów wielolekoopornych $S$. epidermidis izolowanych z powierzchni protez może świadczyć o ogólnej tendencji do wzrostu lekooporności bakterii różnych gatunków na protezach u osób po przeszczepie nerki. Bakterie MDR, które wywołują objawowe zakażenia mogą w skrajnych sytuacjach doprowadzić osoby chore do śmierci, gdyż stosowane antybiotyki nie wykazują wobec tych drobnoustrojów skuteczności. Przeprowadzenie dalszych badań obejmujących szereg innych rodzajów mikroorganizmów byłoby zatem wskazane aby potwierdzić lub zaprzeczyć powyższemu wnioskowi. W świetle mikrobiologicznych przyczyn powikłań poprzeszczepowych wniosłoby to 
niezwykle cenne informacje, które pozwoliłyby zmodyfikować lub opracować nowe metody profilaktyki przeciwinfekcyjnej, które uwzględniałyby przykładowo okresowe dezynfekcje lub sterylizacje protez zębowych.

Powiązania między dawkami leków immunosupresyjnych, schematów leczenia i obecnością określonych bakterii $\mathrm{w}$ jamie ustnej stanowią nadal mało poznany obszar wiedzy. Niniejsze badania sygnalizują dalszą potrzebę zgłębiania tematyki i wdrażania terapii immunosupresyjnych bezpiecznych dla osób leczonych nerkozastępczo przeszczepem narządowym, które uwzględniają status mikrobiologiczny jednego z ważniejszych rezerwuarów drobnoustrojów, jakim jest jama ustna.

\section{References / Piśmiennictwo}

1. Snydman D: Epidemiology of infections after solid-organ transplantation. Clin Infect Dis 2001; 33: 5-8.

2. Pop-Vicas A, Strom J, Stanley K, D'Agata E: Multidrug-Resistant Gram-Negative Bacteria among Patients Who Require Chronic Hemodialysis. Clin J Am Soc Nephrol 2008; 3: $752-758$.

3. Cosgrove SE, Qi Y, Kaye KS, Harbarth S, et al: The impact of methicillin resistance in Staphylococcus aureus bacteremia on patient outcomes: mortality, length of stay, and hospital charges. Infect Control Hosp Epidemiol 2005; 26: 166-174.

4. Cosgrove SE: The relationship between antimicrobial resistance and patient outcomes: mortality, length of hospital stay, and health care costs. Clin Infect Dis 2006; 42: 82-99.

5. Shurland S, Zhan M, Bradham DD, Roghmann $M C$ : Comparison of mortality risk associated with bacteremia due to methicillin-resistant and methicillin-susceptible Staphylococcus aureus. Infect Control Hosp Epidemiol. 2007; 28: 273-279.

6. Linares L, Cervera C, Cofán F, Ricart MJ, et al: Epidemiology and outcomes of multiple antibiotic-resistant bacterial infection in renal transplantation. Transplant Proc 2007; 39: 2222-2224.

7. Diaz PI, Hong BY, Frias-Lopez J, Dupuy
$A K$, et al: Transplantation-associated longterm immunosuppression promotes oral colonization by potentially opportunistic pathogens without impacting other members of the salivary bacteriome. Clin Vaccine Immunol 2013; 20: 920-930.

8. Okeke IN, Laxminarayan $R$, Bhutta ZA, Duse $A G$, et al: Antimicrobial resistance in developing countries. Part I: recent trends and current status. Lancet Infect Dis 2005; 5: 481493.

9. Vernet $G$, Mary $C$, Altmann DM, Doumbo $O$, et al: Surveillance for antimicrobial drug resistance in under-resourced countries. Emerg Infect Dis 2014; 20: 434-441.

10. Perlin DS, Rautemaa-Richardson R, AlastrueyIzquierdo A: The global problem of antifungal resistance: prevalence, mechanisms, and management. Lancet Infect Dis 2017; 17: e383-e392.

11. Vandecasteele SJ, De Vriese AS: Recent changes in vancomycin use in renal failure. Kidney Int 2010; 77: 760-764.

12. Alibayov B, Baba-Moussa L, Sina $H$, Zdeňková $K$, et al: Staphylococcus aureus mobile genetic elements. Mol Biol Rep. 2014; 41: 5005-5018.

13. Rossi CC, Souza-Silva T, Araújo-Alves AV, Giambiagi-deMarval $M$ : CRISPR-Cas Systems Features and the Gene-Reservoir 
Role of Coagulase-Negative Staphylococci. Front Microbiol 2017; 8: 1545.

14. Calfee DP: Multidrug-resistant organisms in dialysis patients. Semin Dial 2013; 26: 447456.

15. Smith AJ, Jackson MS, Bagg J: The ecology of Staphylococcus species in the oral cavity. J Med Microbiol 2001; 50: 940-946.

16. Hussein K, Sprecher H, Mashiach T, Oren I, et al: Carbapenem resistance among Klebsiella pneumoniae isolates: risk factors, molecular characteristics, and susceptibility patterns.
Infect Control Hosp Epidemiol 2009; 30: 666-667.

17. Schwaber MJ, Klarfeld-Lidji S, NavonVenezia S, Schwartz D, et al: Predictors of carbapenem-resistant Klebsiella pneumoniae acquisition among hospitalized adults and effect of acquisition on mortality. Antimicrob Agents Chemother. 2008; 52: 1028-1033.

Zaakceptowano do druku: 31.01.2019 r.

Adres autorów: 02-006 Warszawa, ul. Nowogrodzka 59.

C Zarząd Główny PTS 2019. 